\title{
Regulation of corpus luteum development and maintenance: specific roles of angiogenesis and action of prostaglandin $F_{2 \alpha}$
}

\author{
A Miyamoto ${ }^{1}$, K Shirasuna ${ }^{1}$, T Shimizu', H Bollwein ${ }^{2}$ and D Schams ${ }^{3}$ \\ 'Graduate School of Animal and Food Hygiene, Obihiro University of Agriculture and Veterinary \\ Medicine, Obihiro 080-8555, Japan; ${ }^{2}$ Clinic for Cattle, University of Veterinary Medicine \\ Hannover, D-30173 Hannover, Germany; Institute of Physiology, Technical University of Munich, \\ Weihenstephaner Berg 3, D-85350 Freising, Germany
}

Development of the corpus luteum (CL) in ruminants occurs in a rapid and time-dependent manner within 1 week after ovulation, with morphologic and biochemical changes in the cells of the theca interna and granulosa cells of the preovulatory follicle. These changes involve luteinisation of steroidogenic cells and angiogenesis to establish normal luteal function (progesterone secretion). The $\mathrm{CL}$ is composed of a large number of vascular endothelial cells, large and small steroidogenic luteal cells, smooth muscle cells, pericytes, fibrocytes and immune cells, indicating that the $\mathrm{CL}$ is a heterogeneous tissue. Moreover, the $\mathrm{CL}$ produces and secretes growth factors (fibroblast growth factor, vascular endothelial growth factor and insulin-like growth factor), vasoactive factors (nitric oxide, angiotensin II and endothelin-1), steroids (progesterone is important for its own production), oxytocin and prostaglandins $\left(\mathrm{PGF}_{2 \alpha}\right.$ and $\mathrm{PGE}_{2}$ ) to regulate luteal formation and development. Clearly, the main function of the $\mathrm{CL}$ is to produce progesterone, which is a prerequisite for survival of the embryo, implantation and maintenance of pregnancy. Inadequate luteinisation and angiogenesis during the early luteal phase results in poor progesterone secretion and causes compromised embryo development and reduced fertilify. Secretion of adequate amounts of progesterone during luteal development requires "precise luteinisation" of theca and granulosa cells to form luteal cells, neovascularization, and the establishment of a blood supply (angiogenesis). PGF ${ }_{2 \alpha}$ in the developing $\mathrm{CL}$ acts as a local regulator to enhance progesterone secretion directly and indirectly by stimulating angiogenic factors, VEGF and FGF2. The preceding role of $\mathrm{PGF}_{2 \alpha}$ may explain why the developing $\mathrm{CL}$ does not acquire luteolytic capacity until several days following ovulation. The balance between luteotrophic and luteolytic factors as well as stimulation and inhibition of angiogenic factors during luteal formation, development and maintenance can have a profound effect on the fate of the CL. 


\section{A brief historical overview of corpus luteum research in ruminants}

As summarized by McCracken et al. (1999), Coiter (1573) described the presence of cavities filled with a yellow solid in the rodent ovary. De Graaf and Mullierum (1943) provided the first definitive description of these structures and noted that the number appeared to be related to the number of fetuses in the uterus. Malpighi (1897) provided an accurate microscopic description of these structures and was the first to name the corpus luteum (CL). Subsequently, Beard (1897) postulated that CL were responsible for the suppression of ovulation and oestrus during pregnancy.

Frenkel (1903) demonstrated that corpora lutea are necessary for implantation and the subsequent maintenance of pregnancy in rabbits. Corner \& Allen (1929) prepared a relatively pure alcoholic extract of the CL from sows and demonstrated that the extract could maintain pregnancy in ovariectomized rabbits. In 1934, isolation of the pure crystalline hormone was reported by different groups (Slotta et al. 1934; Wintersteiner \& Allen 1934). Slotta et al. (1934) named the compound progesterone and suggested the structure. In 1960, about 27 papers concerning the CL with only one in ruminants were cited according to PubMed. From 1960 onwards, countless studies have been performed on different aspects of luteal formation, maintenance, function and regression during the oestrous cycle and pregnancy. A critical advance in the field has been development of sophisticated methods for measuring progesterone in tissue, culture supernatants, and peripheral blood. Research activities have been directed towards the topics listed below (Fig. 1).

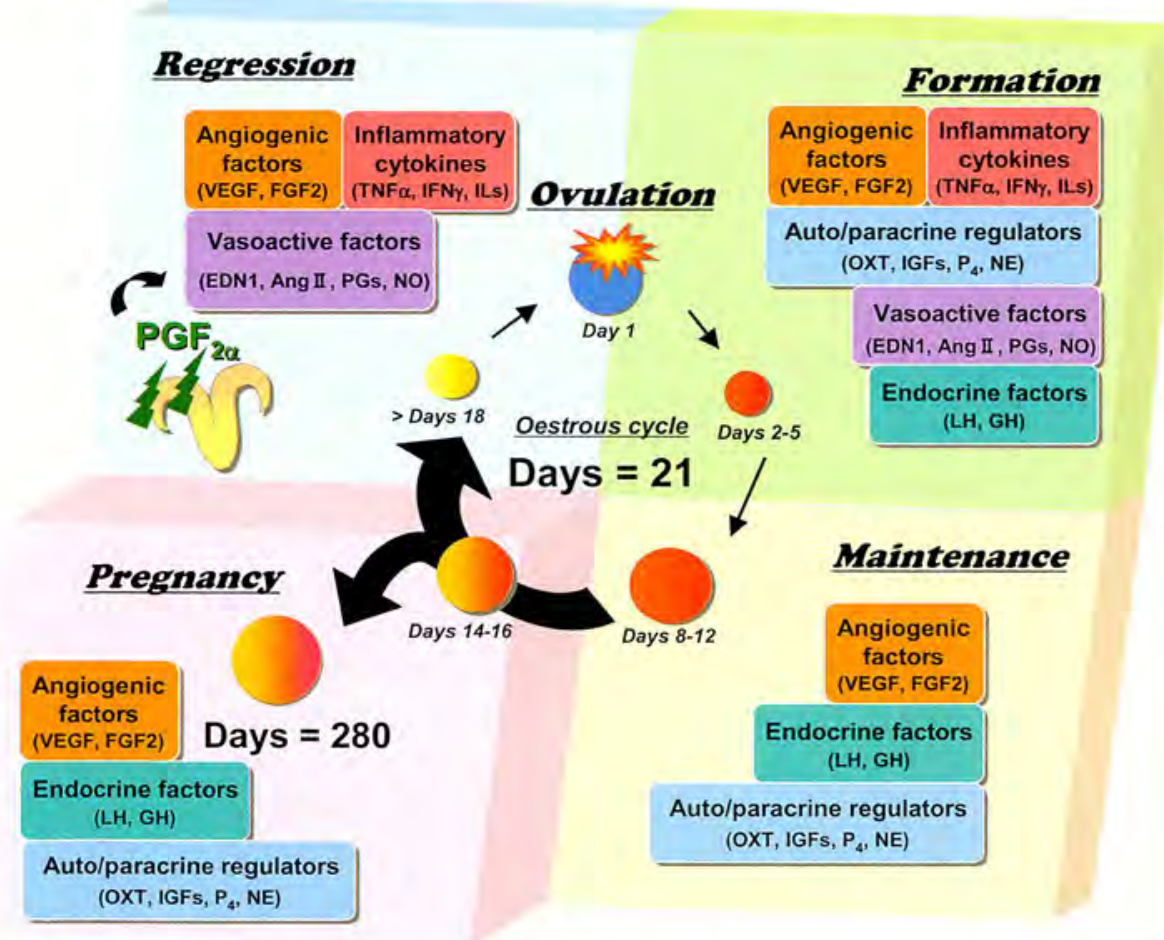

Fig. 1. Schematic presentation of possible involvement of various functional factors during different stages of $\mathrm{CL}$ activity. The $\mathrm{CL}$ at each stage is regulated by a complex mechanism that consists of endocrine factors, auto/paracrine factors, angiogenic factors, vasoactive factors and inflammatory cytokines. The balance between luteotrophic and luteolytic factors as well as stimulation and inhibition of angiogenic factors is the basic mechanism for $\mathrm{CL}$ development, maintenance and regression. 
Development of the corpus luteum

An essential step in early CL development is vascularisation of granulosa-lutein cells through angiogenesis. Angiogenesis is defined as the generation of new blood vessels through sprouting from preexisting blood vessels. This process includes breakdown of basement membranes, proliferation and migration of endothelial cells into the extracellular matrix and formation of new capillary lumina along with functional maturation which is regulated by a complex of stimulation and inhibition of angiogenic factors (Schams \& Berisha 2004). In cows, sprouting endothelial cells invade the developing $C L$ and continue to grow throughout the first third of the ovarian cycle, and the mature CL is characterized by a dense network of vessels with gradually decreasing vessel density. During luteolysis, all newly formed blood vessels regress, thus luteal angiogenesis is a suitable experimental system to study endothelial cells in sprouting and regressing blood vessels (Augustin et al, 1995).

\section{Molecular control of luteal secretion of progesterone}

The synthesis and secretion of progesterone are regulated by two morphologically and biochemically distinct steroidogenic cell types in the CL. Small luteal cells respond to luteinising hormone (LH) or CAMP with an increase in secretion of progesterone. Large luteal cells secrete a high basal concentration of progesterone ( $\geq 85 \%$ ), do not respond to LH or CAMP and contain receptors for prostaglandin $(\mathrm{PG}) \mathrm{F}_{2 \alpha^{\prime}}$ growth hormone $(\mathrm{GH})$ and other proteins. Progesterone secretion is regulated by two second messenger pathways. Phosphorylation of steroid acute regulatory (StAR) protein by protein kinase $A$ (PKA) stimulates cholesterol transport, whereas phosphorylation by PKC appears to inhibit this process and induces cell death (Niswender et al. 2000).

\section{Trophic regulation of luteal function}

Both LH and GH are necessary for normal luteal development and function (Niswender et al. 2000; Schams \& Berisha 2004). Local regulators such as growth factors (insulin-like growth factors, IGFs; fibroblast growth factors, FGFs), ovarian peptides (oxytocin; angiotensin II, Ang II; endothelin-1, EDN1), and steroids (noradrenalin and prostaglandins ( $\mathrm{PGF}_{2 \alpha}$ and $\mathrm{PGE}$ ): Schams \& Berisha 2004) play modulatory roles acting in an autocrine/paracrine fashion.

\section{Luteal regression (luteolysis)}

After induction of luteolysis by endometrial PGF ${ }_{20}$, a cascade of events occurs within the CL, leading to functional and structural luteolysis. The acute changes in vasoactive factors suggest that modulation of vascular stability is a critical component of luteolysis (Miyamoto et al. 2009). Other cascades after PGF $_{2 a}$-induced luteolysis that occur in parallel or subsequent to changes in vascularity include: (i) luteal nitric oxide (NO) release and blood flow, (ii) up-regulation of inflammatory cytokines and luteal cell apoptosis factors, (iii) up-regulation of vasoactive peptides in luteal cells, (iv) extracellular matrix proteases associated with $\mathrm{CL}$ tissue remodelling and (v) invasion by immune cells (monocytes, macrophages, T-lymphocytes) from the blood stream after monocyte chemoattractant protein-1 up-regulation.

There are currently (PubMed) about 14,813 papers concerning the $C L$ in different species. About 4,238 of these papers concern domestic ruminants. However, there are a number of important issues relating to luteal function that require further research. For example, a 
clearer understanding of how the balance between luteotrophic and luteolytic factors as well as stimulation and inhibition of angiogenic factors affects luteal function is essential. In addition, we need to better understand the role of proteolytic processes (e.g. tissue remodelling), and modulation by the immune system in the regulation of the CL. A schematic of possible involvement of these factors in different stages of the luteal phase is shown in Fig. 1. In this review, we focus on $\mathrm{CL}$ development and maintenance in ruminants with specific emphasis on luteal angiogenesis and the action of prostaglandins.

\section{Introduction}

Ovulation occurs in response to a cascade of morphological, biochemical, and physiological changes in the Graafian follicle following the LH surge, resulting in expulsion of the matured oocyte and subsequent development of the $\mathrm{CL}$. The bovine $\mathrm{CL}$ develops rapidly within 2-3 $\mathrm{d}$ after ovulation and is supported by differentiation and hypertrophy of steroidogenic cells, angiogenesis and neovascularisation; it is functional for $17-18 \mathrm{~d}$ in the non-pregnant cow. If pregnancy does not occur successfully, the CL must regress within a few days to allow for subse-

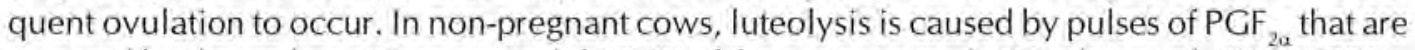
secreted by the endometrium around d 17-19 of the oestrous cycle (Ginther et al. 2009). PGF induces a decrease in luteal blood flow which results in a decrease in progesterone released from the $\mathrm{CL}$ as well as a decrease in $\mathrm{CL}$ volume (Acosta et al. 2002; Niswender et al. 1976).

The preovulatory follicle is compartmentalised into a highly vascular thecal layer and a nonvascular granulosal layer that are separated by a basal membrane and independently regulated by $\mathrm{LH}$ and FSH. The $\mathrm{CL}$ is composed of a large number of vascular endothelial cells that can account for up to $50 \%$ of all luteal cells. Large and small steroidogenic luteal cells constitute about $30 \%$ of all cells of CL (O'Shea et al. 1989), and the majority of steroidogenic cells are adjacent to one or more capillaries (Zheng et al. 1993). The bovine CL also consists of various cell types such as smooth muscle cells, pericytes, fibrocytes and immune cells, indicating that it is a heterogeneous tissue (Farin et al. 1986). The bovine CL produces steroid hormones, PGs (Miyamoto et al. 1993; Shemesh \& Hansel 1975), a number of angiogenic factors, and other local regulators (Reynolds et al. 2000; Schams \& Berisha 2004).

\section{Changes in the dominant follicle before and after the $\mathrm{LH}$ surge}

\section{Preovulatory changes induced by the LH surge}

The time between the $\mathrm{LH}$ surge and ovulation is a critical period for the rapid start of differentiation of the preovulatory follicle. The $\mathrm{CL}$ is formed after ovulation from remaining follicular cells. The preparation of luteal cells for progesterone synthesis begins before ovulation. Luteinisation and secretion of progesterone can occur in the absence of ovulation in cattle (Kesler et al. 1981) and sheep (Murdoch \& Dunn 1983), indicating that mechanisms associated with luteinisation are not dependent on follicular rupture. Following the preovulatory LH surge but before ovulation, follicular cells begin morphological, endocrinological and biochemical changes associated with luteinisation. The critical roles of PGs in ovulation have been demonstrated by an experiment in which an inhibitor of PG biosynthesis effectively inhibited ovulation in cattle (Algire et al. 1992). Injection of an ovulatory dose of hCG induced expression of cyclooxygenase-2 (COX-2) in the granulosa cells of bovine preovulatory follicles (Sirois 1994). The levels of PGF ${ }_{2 \alpha}$ and PGE increased by more than 100 -fold at $25 \mathrm{~h}$ after the endogenous LH surge in bovine preovulatory follicular fluid (Short et al. 1995). Additionally, Ang II, a potent 
vasoconstrictive factor, as well as $\mathrm{PGF}_{2 \alpha}$ acutely increased around the time of ovulation in the bovine mature follicle in vivo (Acosta et al. 2000). FGF2 protein is up-regulated beginning with the LH surge, and the maximum levels were observed at $20 \mathrm{~h}$ after $\mathrm{GnRH}$ injection in the bovine follicle (Berisha et al. 2006). Interestingly, FGF2 localisation changed dramatically from the theca (cytoplasm of endothelial cells) to the nucleus of granulosa cells after the LH surge, suggesting an essential role for survival of granulosa cells or for transition of granulosa cells to luteal cells (Berisha et al. 2006). Oxytocin also plays important autocrine/paracrine roles in the follicular/luteal transition of steroidogenesis from estradiol/androgen to progesterone production. Oxytocin not only stimulates progesterone, but also inhibits oestradiol secretion by granulosa cells before the LH surge, but not after the LH surge (Berndtson et al. 1996; Voss \& Fortune 1991). In addition, oxytocin stimulates progesterone release from early developing CL as examined with the microdialysis system (Miyamoto \& Schams 1991).

Vascular changes are associated with the cyclic remodelling of ovarian tissue that occurs during final stages of follicular growth, ovulation and CL development (Acosta et al. 2002; Moor et al, 1975). The principal angiogenic factors controlling follicular angiogenesis are FGF2 and VEGFA (Berisha et al. 2000b). Systemic administration of a VEGF antagonist prevented the development of preovualtory follicles. This inhibition was associated with a decrease in thecal layer vasculature, granulosa cell proliferation, antral formation and steroidogenesis (Wulff et al. 2002). Conversely, ovarian injection of VEGFA gene fragments into gonadotropin-stimulated prepubertal pigs increased thecal vascularisation and the number of preovulatory follicles (Shimizu et al. 2003). The follicular VEGFA concentration in the fluid and tissue increased in the bovine follicles during final maturation and was associated with increased vascular density in the thacal layer (Berisha et al. 2000b). Vessel permeability increased along with neovascularisation of the follicular periphery, thereby supplying a larger effective dose of $\mathrm{LH}$ to that particular follicle. LH stimulated VEGFA expression in bovine cultured granulosa cells in a dose dependent manner (Schams et al. 2001). As VEGFA mRNA expression is not altered by the $\mathrm{LH}$ surge during the periovulatory interval, $\mathrm{LH}$ is thought to act at a post-transcriptional level to regulate VEGFA production (Hazzard et al. 1999). Capillaries induced by VEGF develop perforations through which blood cells and platelets escape when ovulation occurs. Shortly before ovulation, blood flow stops in a small area of the ovarian surface overlying the bulging follicles. This area, known as the stigma, then ruptures (Findlay 1986).

\section{Follicular luteinisation after ovulation}

After follicular rupture, there is a dramatic invagination of the follicular wall that presumably facilitates migration of fibroblasts, endothelial cells and theca interna cells into the central regions of the developing CL. Tissue remodelling and cellular migration are facilitated by breakdown of the basement membrane that separates the avascular granulosa cell layer from the theca interna layer. Small and large luteal cells are derived exclusively from theca and granulosa cells, respectively. However, some small luteal cells may differentiate into large luteal cells (Alila \& Hansel 1984). Conversely, some large luteal cells may differentiate into small luteal cells (Fisch et al. 1989). In sheep, small luteal cells can stimulate angiogenesis (Grazul-Bilska et al. 1991).

The differentiation of granulosa and theca cells into large and small luteal cells is characterized by increased progesterone production. The preovulatory $\mathrm{LH}$ surge initiates distinct changes in both expression and regulation of steroidogenic enzymes and is a key event in the luteinisation process. Aromatase cytochrome P-450 enzyme (P450arom) is a key enzyme in oestradiol biosynthesis, catalyzing aromatisation of C19 androgens of theca cell origin to C18 
oestrogens within granulosa cells. P450arom mRNA decreases in bovine follicles collected at approximately $20 \mathrm{~h}$ after the LH surge (Voss and Fortune 1993). Within the bovine CL, 3Bhydroxysteroid-dehydrogenase (3B-HSD) mRNA and enzyme activity increases throughout most of oestrus and then decreases during luteolysis (Couet et al. 1990). Moreover, 3B-HSD enzyme activity is greater in the bovine CL than in preovulatory follicles (Couet et al. 1990). Thus, 3B-HSD activity within the CL facilitates high rates of progesterone biosynthesis.

During luteinisation, the changes in gene expression associated with steroid production in steroidogenic cells are regulated by transcription factors such as Ad4BP/SF-1 and DAX-1. The decrease in DAX-1, a suppressor of Ad4BP/SF-1, is involved in acquisition of the ability to produce progesterone when granulosa cells are luteinising (Shimizu et al. 2009). However, during luteinisation of theca cells in culture, suppression of CYP 17 genes was induced by an increase in DAX-1 transcription factor (Murayama et al. 2008). Thus, DAX-1 likely contributes to the expression of specific genes to shift steroid production during luteinisation of granulosa and theca cells.

\section{Corpus luteum development and angiogenesis}

Vasculature of the developing $\mathrm{CL}$

After ovulation, a rich vascular network is established within the CL to support differentiation of follicular cells and progesterone secretion from luteal cells during the early luteal phase. Functionally, luteal blood vessels can be divided roughly into two types of blood vessels. One type is arteriolovenous vessels, i.e., arteriola (diameter: about $40 \mu \mathrm{m}$ ) and venula vessels (diameter: about $30 \mu \mathrm{m}$ ), which have a smooth muscle layer and exhibit a vasorelaxant effect. In the circulation of blood, the arteriola connects to microcapillary vessels followed by venulae (Kashiwagi et al. 2002). It has been reported that in the rabbit CL, arteriolovenous vessels exist in the periphery of the CL (Wiltbank et al. 1988), and luteal blood flow is observed mainly in the periphery of the bovine CL in color Doppler images (Acosta et al. 2002). The other types are capillary vessels having no smooth muscle layer and thus exhibit little vasorelaxant effect. In the bovine and ovine $\mathrm{CL}$, the number of arteriolovenous and microcapillary vessels drastically increases from the early to mid-luteal phase (Bauer et al. 2003; Hojo, et al. 2009; Shirasuna et al. 2010a), indicating active angiogenesis during this period. A recent study indicated that further angiogenesis does not occur throughout the period of early maternal recognition in the cow (Beindorff et al. 2010).

\section{Role of angiogenic factors in the developing $\mathrm{Cl}$}

Angiogenesis is a critical component of normal luteal function. In 1906, Loeb (1906) indicated that the CL closely resembles "transitory tumors", and the rate of luteal growth is equivalent to the fastest growing tumors. Therefore, the growth of blood vessels and establishment of a blood supply are essential during early luteal development. Indeed, the mature $\mathrm{CL}$ has the densest capillary network system in the whole body and each luteal cell is adjacent to one or more capillaries.

One of the major angiogenic factors, FGF2, is generally involved in cell growth, differentiation, transformation and angiogenesis. Gospodarowicz et al,. (1985) showed that FGF2 is produced in the bovine $\mathrm{CL}$ and stimulates neovascularization and proliferation of a variety of cells such as vascular smooth muscle cells, granulosa cells and endothelial cells. The mRNA expression of FGF2 and its receptor is highest during the early luteal phase (Berisha et al. 
2000a; Schams et al. 1994). FGF2 concentrations in CL tissue are high during the early luteal phase, and decrease significantly in the mid-luteal phase during the oestrous cycle in the cow (Schams et al. 1994). FGF2 stimulates progesterone secretion from the early bovine $\mathrm{CL}$ as determined using a microdialysis system (Miyamoto et al. 1992). In a recent study investigating the impact of FGF2 on bovine CL development and function, an FGF2 antibody was injected directly into the $\mathrm{CL}$ (Yamashita et al. 2008). This treatment markedly suppressed CL volume and progesterone synthesis (plasma progesterone concentrations and mRNA expression of StAR) as well as decreased mRNA expression of key factors related to angiogenesis (VEGF ${ }_{120}$ FGF2, FGFR-1) and increased the ratio of angiopoietin-2/angiopoietin-1 (an index of instability of vessels), all of which promote angiolysis (Yamashita et al. 2008). This suggests that FGF2 promotes the establishment of a new vascular network and luteal function during $\mathrm{CL}$ formation in the cow.

The greatest mRNA expression for VEGFA and VEGFR-2 in the CL was detected during the early luteal phase followed by a significant decrease in expression during the mid and lateluteal phase, with further decreases after luteal regression in the cow (Berisha et al. 2000b). In contrast, VEGFR-1 mRNA expression did not change during the oestrous cycle (Berisha et al. $2000 \mathrm{~b})$. The concentration of VEGF protein was increased during the early luteal phase and then decreased, especially in the regressing $\mathrm{CL}$ (Berisha et al. 2000b). VEGFA can stimulate progesterone secretion from the bovine CL (Kobayashi et al. 2001). An injection of VEGF antibody into an intact bovine $\mathrm{CL}$ suppressed the increase in $\mathrm{CL}$ volume and progesterone synthesis in the early CL (Yamashita et al. 2008). These findings are in agreement with the previous report that neutralisation of VEGF using an antibody during the early luteal phase in marmoset monkeys inhibits proliferation of endothelial cells and plasma progesterone concentrations (Fraser et al. 2000).

Robinson et al,. (2008) investigated the angiogenic and luteotropic roles of FGF2 and VEGF in the bovine $\mathrm{CL}$. using an in vitro culture system for luteal angiogenesis. Luteal FGF2 concentration was highest from d 1-2 compared with d 3-4, 5-6 and 8-12 of the oestrous cycle, while luteal VEGF concentration gradually increased from the early to midcycle $\mathrm{CL}$, and then decreased in the regressing CL in the cow (Robinson et al. 2009). In a luteal angiogenesis culture system (includes luteal cells, endothelial cells and smooth muscle cells), a physiological dose (1 ng/ml) of FGF2 and VEGF stimulated the extent of the endothelial cell network (Fig. 2; Robinson et al. 2008). Using this culture system, a VEGFR2 inhibitor resulted in lower numbers of endothelial networks compared with the control (60\% of the control; Woad et al. 2009). However, even in the presence of VEGF, a FGFR1 inhibitor drastically reduced the number of vascular networks by more than $90 \%$, suggesting that FGF2 is more crucial than VEGF for forming luteal vascular networks (Fig. 2; Woad et al. 2009). The preceding findings indicate that FGF2 plays a key role in the initiation of angiogenesis during very early luteal development in the cow.

In the early CL, FGF2 was localised to endothelial cells but the localization changed to the cytoplasm of luteal cells after 5 to $7 \mathrm{~d}$ (Schams et al. 1994). VEGFA (mainly localised in the cytoplasm of luteal cells) plays a fundamental role in maintenance of the luteal vasculature following cessation of luteal growth when active angiogenesis is no longer occurring. Indeed, VEGF enhanced endothelial platelet-derived growth factor (PDGF)-BB, a potent stimulator of neovascularisation; whereas, FGF2 enhanced PDGF receptor expression in pericytes and smooth muscle cells surrounding vasculature (Kano et al. 2005). Stimulation with VEGF and FGF2 caused a significant pericyte/muscle cell recruitment and formation of vasculature compared with single-agent stimulation, indicating a different contribution of both factors in neovascularisation (Kano et al. 2005). 

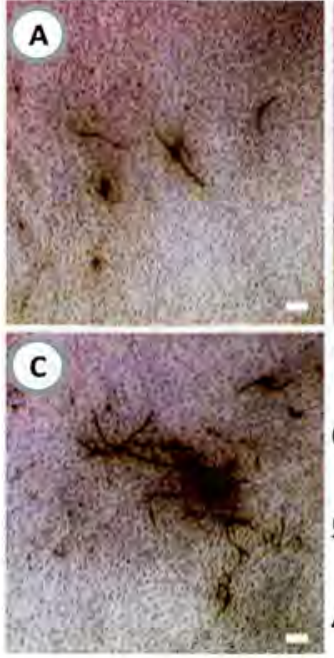

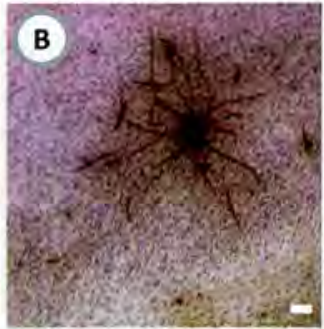

(D) VWF staining area (Log, $\mu \mathrm{m}^{2}$ )

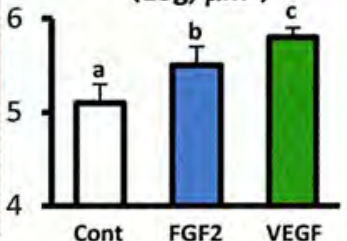

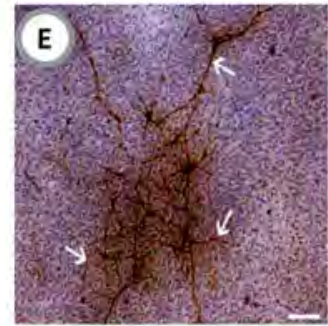
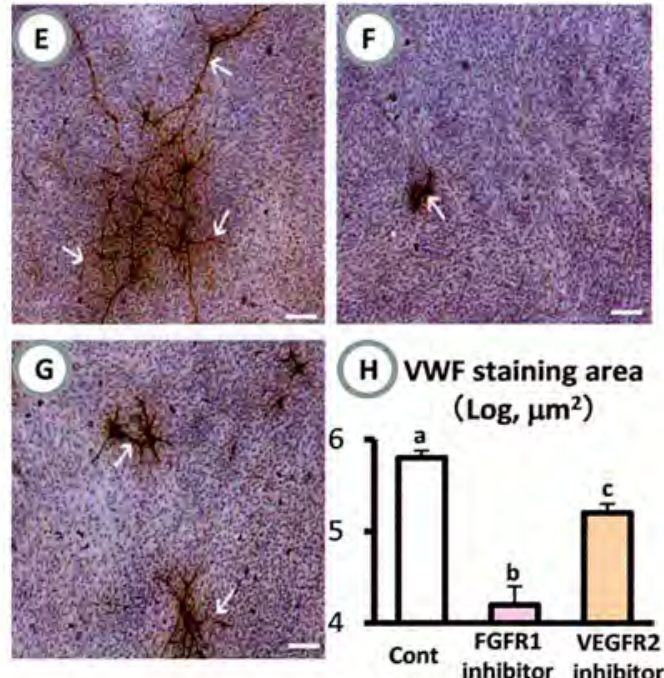

Fig. 2. The effect of FGF2, VEGFA and inhibitors of angiogenesis on the development of the luteal endothelial network in vitro (modified from Robinson et al., 2009; Woad et al., 2009). Luteal cells were dispersed from early CLs. In Figure 2D, luteal cells were treated with control (open bar, Fig. 2A), 1 ng/ml FGF2 (blue bar, Fig. 2B), and 1 ng/ml VEGFA (green bar, Fig. 2C) for 9 days. In Figure $2 \mathrm{H}$, the luteal cells were treated either with control medium containing $1 \mathrm{ng} / \mathrm{ml}$ FGF2 and VEGFA (Cont, open bar), plus $1 \mu \mathrm{MFGFR} 1$ inhibitor (SU5402, pink bar) and $2 \mu \mathrm{M}$ VEGFR2 inhibitor (SU1498, orange bar) for 9 days. The endothelial cells were immunostained (brown) with von Willbrand Factor (VWF). The scale bar represents $50 \mu \mathrm{m}$. Following image analysis and quantification of VWF immunostaining, the effects of angiogenic factors and inhibitors of angiogenesis are shown on total area of VWF in Fig. 2D and $2 \mathrm{H}$. The significant differences $(P<0.05)$ between treatment groups are indicated by different letters and the values are meant + S.E.M.

\section{Potential interaction between cytokines and angiogenesis in the developing $\mathrm{CL}$}

The early $\mathrm{CL}$ produces angiogenic and luteotropic factors. Tumor necrosis factor- $\alpha$ (TNF $\alpha$ ) is recognised as a tumoricidal factor produced by activated macrophages and luteal cells; TNF $\alpha$ and its receptors are detected in the early CL (Sakumoto et al. 2000). TNF $\alpha$ is a representative angiogenic factor regulating VEGF and FGF2 in bovine retinal cells (Yoshida et al. 2004). Interleukin (IL)-1 and IL-8, mainly produced by activated monocytes and macrophages, are also good candidates as angiogenic factors. Indeed, IL- $1 \alpha$ and IL-1 $\beta$ can up-regulate VEGF expression in endometriotic stromal cells ( $\mathrm{Li}$ et al. 1995). Koch et al., (1992) indicated that IL-8 can induce the same levels of chemotaxis, proliferation and angiogenesis in human endothelial cells as FGF2. These findings lead to the hypothesis that various cytokines effectively coordinate to promote angiogenesis and ensure luteal development and function.

Extracellular matrix (ECM) is crucial for angiogenesis and tissue remodeling. Matrix metalloproteinases (MMPs) cleave specific components of the ECM and are inhibited by tissue inhibitors of metalloproteinases (TIMPS). MMPs and TIMPs play a major role in the process of follicular development and atresia, ovulation and CL development, maintenance and regression. A detailed mechanism of MMP-TIMP system in the ruminant $\mathrm{CL}$ was nicely reviewed previously (Curry \& Smith 2006; Smith et al. 1999). 


\section{Distinct regulatory mechanisms of $\mathrm{PGF}_{2 \alpha}$ in the early and midcycle $\mathrm{CL}$}

An intriguing question concerning bovine CL function in recent years is "Why is the developing $\mathrm{CL}$ ( $\mathrm{d} 1$ to 5 of the oestrous cycle) resistant to the luteolytic action of $\mathrm{PGF}_{2 \alpha}$; whereas, after $\mathrm{d}$ 5 exogenous PGF $_{2 \alpha}$ can induce rapid luteolysis?" (Henricks et al. 1974; Levy et al. 2000). To investigate the mechanisms underlying the different actions of $\mathrm{PGF}_{20}$ in the early $\mathrm{CL}$ (PGF $2 u^{-}$ resistant) versus midcycle $C L\left(\mathrm{PGF}_{2 a}\right.$-responsive) in domestic animals, several studies have focused on potential differences in steroidogenesis (Tsai \& Wiltbank 1998), prostaglandin synthesis (Silva et al. 2000; Tsai \& Wiltbank 1997b), immune function (Tsai et al. 1997a) and vasoactive factors (Choudhary et al. 2004; Levy et al. 2000; Wright et al, 2001). Although $\mathrm{PGF}_{z \alpha}$ acutely decreased mRNA expression of $3 \beta-H S D$ in both the early and midcycle $\mathrm{CL}$, PGF $_{2 a}$ decreased StAR mRNA expression in the midcycle CL but not in the early CL. (Tsai \& Wiltbank 1998), indicating that StAR may be a key factor in reduced steroidogenesis following PGF $_{2 \alpha}$ administration in the cow.

Prostaglandin $\mathrm{F}_{2 a}$ receptor ( $\mathrm{FPr}$ ) mRNA is expressed in the $\mathrm{CL}$ at high levels throughout the oestrous cycle (Sakamoto et al. 1995; Wiltbank et al. 1995). Shirasuna et al., (2008) showed that FPr was localised to luteal cells but also to large blood vessels (mainly endothelial cells) in the periphery of the early and midcycle CL. The presence of FPr in the early CL can induce a specific tissue response (Levy et al. 2000; Tsai \& Wiltbank 1998). Indeed, these previous reports indicated that FPr mRNA expression was decreased by PGF $_{2 a}$ administration at both stages (Levy et al. 2000; Tsai \& Wiltbank 1998). Thus, the refractoriness of the early CL to the luteolytic effect of $\mathrm{PGF}_{2 \alpha}$ is not caused by a lack of the FPr.

\section{Angiogenic factors}

In a study focusing on the response of angiogenic factors to $\mathrm{PGF}_{2 \alpha}$ administration, $\mathrm{PGF}_{2 \alpha}$ injection down-regulated mRNA expression of VEGFA and FGF2 in the midcycle CL (Shirasuna et al. 2010b), suggesting that inhibiting angiogenesis may initiate or at least contribute to luteolysis. PGF $_{2 a}$ administration drastically decreased VEGF protein expression, in the bovine midcycle $\mathrm{CL}$, after $30 \mathrm{~min}$ (Berisha et al. 2010). Interestingly, in the early CL (d 4 of the oestrous cycle), PGF $_{212}$ stimulated mRNA expression of VEGFs and FGF2 (Shirasuna et al. 2010b) and PGF up-regulated VEGF transcription in human cancer cells (Sales et al. 2005). Moreover, both the production of $\mathrm{PGF}_{2 \alpha}$ and $\mathrm{mRNA}$ expression of COX-2 were higher in the early CL compared to other stages of the luteal phase (Kobayashi et al. 2001; Milvae \& Hansel 1983). Importantly, in the bovine early $\mathrm{CL}, \mathrm{PGF}_{2 a}$ clearly stimulated progesterone secretion (Miyamoto et al. 1993; Okuda et al. 1998), and VEGF and FGF2 stimulated $\mathrm{PGF}_{20 .}$ and progesterone secretion (Kobayashi et al. 2001). Consequently, it is proposed that $\mathrm{PGF}_{2 \alpha^{\prime}}$ in the early $\mathrm{CL}$, acts as a local regulator to enhance progesterone secretion directly and also indirectly by stimulating VEGF and FGF2 (Fig. 3). The preceding mechanism may be one of the main reasons why the early $\mathrm{CL}$ is resistant to the luteolytic effects of $\mathrm{PGF}_{20}$ (Miyamoto et al. 2009).

\section{Insulin-like growth factors}

The insulin-like growth factor (IGF) system is essential for support of progesterone secretion from luteal cells. The bovine and ovine CL have been identified as sites of IGF-I and IGF-II mRNA expression as well as peptide production and action throughout the luteal phase (Einspanier et al. 1990; Khan-Dawood et al. 1994; Sauerwein et al. 1992). The mRNA expression of IGF-I 


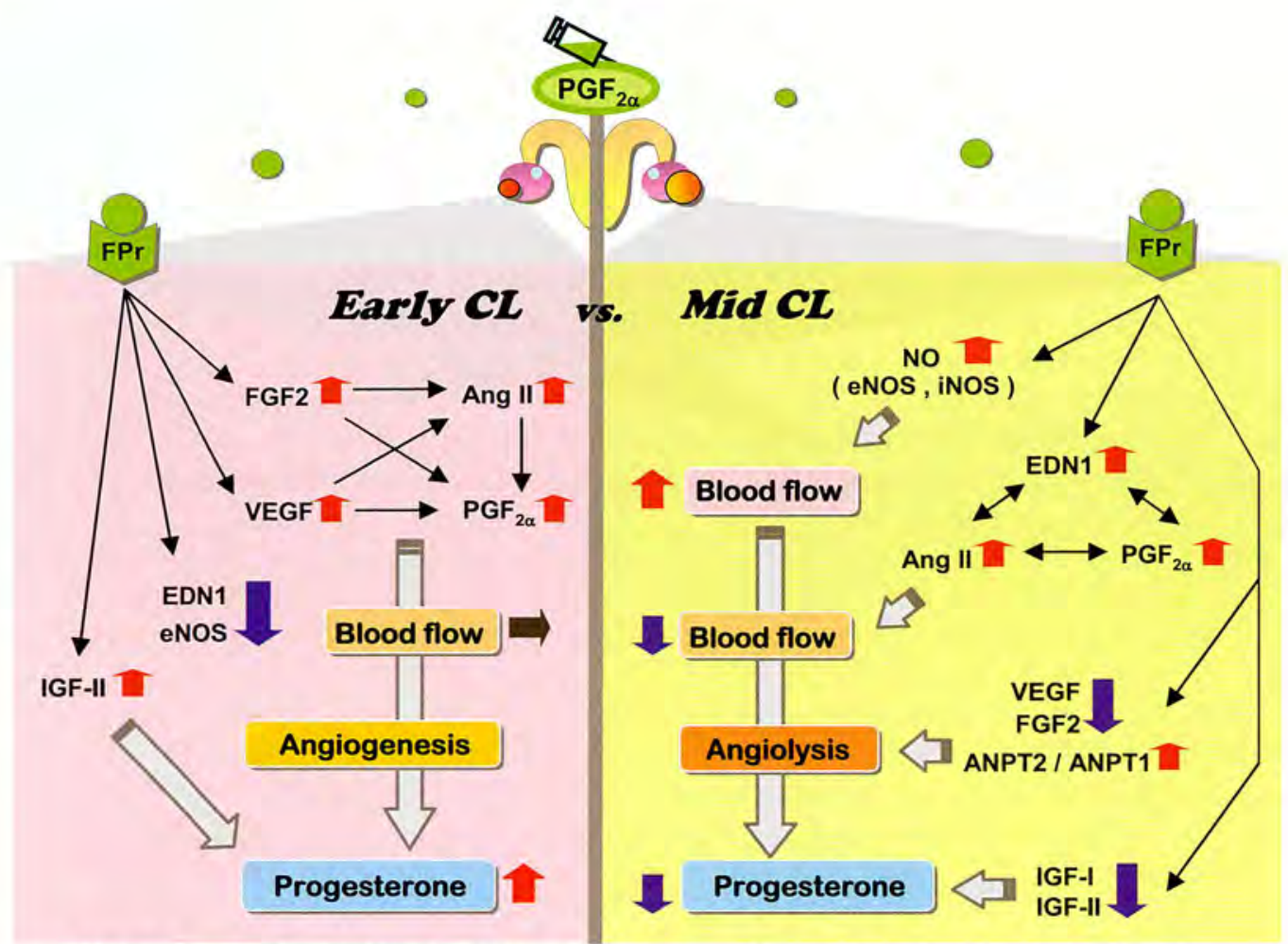

Fig. 3. Proposed model for the differential response of the early and mid-cycle CL to PGF ${ }_{2 \alpha}$ administration in the cow. After PGF $_{2 \alpha}$ injection, PGF $_{2 \alpha}$ enters into the $\mathrm{CL}$ via bloodstream. In the early $\mathrm{CL}, \mathrm{PGF}_{2 \alpha}$ acutely stimulates VEGF, FGF2 and IGF-II expression in the bovine CL. VEGF and FGF2 stimulate luteal Ang II and PGF ${ }_{2 \alpha^{\prime}}$ and Ang II stimulates luteal PGF $2 \alpha^{\text {. }}$ This local positive feedback system between angiogenic and vasoactive factors supports angiogenesis and progesterone secretion within the $\mathrm{CL}$; consequently, the early CL exhibits resistance to the luteolytic effect of $\mathrm{PGF}_{2 \alpha}$. Additionally, $\mathrm{PGF}_{2 \alpha}$ acutely suppresses EDN1 and eNOS expression in the bovine early $\mathrm{CL}$, probably contributing to no response in blood flow.

In the midcycle $\mathrm{CL}, \mathrm{PGF}_{2 \alpha}$ suppresses VEGF and FGF2 expression and creates the increased ratio of ANPT2/ANPT1 (an index of unstability of vessels), initiating angiolysis within the CL. In addition, PGF $_{2 \alpha}$ decreases IGF-I and IGF-II expression directly causing a reduction in progesterone. A luteolytic dose of $\mathrm{PGF}_{2 \alpha}$ stimulates NO production by eNOS and iNOS expression in the $\mathrm{CL}$, thus the luteal blood flow (one of the earliest physiological signs of the luteolytic cascade in the cow) is acutely increased as a result of vasodilation by NO action. Coincidently, vasoactive factors such as EDN1, Ang II and luteal PGF ${ }_{2 \alpha}$ start to increase within the $C L$ to induce severe vasoconstriction. These events are coordinated and induce directly or indirectly the drastic decrease in progesterone secretion.

and IGF-II are higher in the early CL than other stages of the bovine luteal phase (Schams et al. 2002). Also, IGF-I was localised to both large and small luteal cells, whereas, IGF-II was localised to the perivascular fibroblasts of large blood vessels and pericytes of capillaries in the

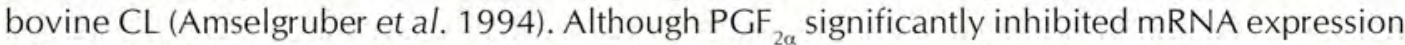
of both IGF-I and IGF-II in the midcycle CL, IGF-II mRNA expression was stimulated by PGF $2 \alpha$ in the early CL (Shirasuna et al. 2010b). Importantly, the stimulatory effect on progesterone 
secretion of IGF-II was greater than that of IGF-I in bovine CL tissue culture (Green et al. 2007). Additionally, IGF-II stimulated the chemotactic motility of endothelial progenitor cells in a dose-dependent manner and increased neovascularisation in the mouse (Maeng et al. 2009). These data suggest that PGF ${ }_{2 \alpha}$ may have potential as an angiogenic and luteotrophic agent in the early $\mathrm{CL}$.

\section{Vasoactive factors}

Vasoactive factors: EDN1, Ang II and NO are involved in the process of luteal regression in ruminants (Acosta et al. 2009; Girsh et al. 1996a; Hayashi \& Miyamoto 1999; Hinckley \& Milvae 2001; Miyamoto et al. 1997; Skarzynski et al. 2000). In fact, EDN1, Ang II and NO can inhibit progesterone secretion in the bovine (Girsh et al. 1996b; Miyamoto et al. 1997; Stirling et al. 1990) and ovine (Hinckley \& Milvae 2001) CL in vitro. Moreover, PGF $_{2 \alpha}$ stimulated biosynthesis of EDN1 (and EDN1 mRNA expression), Ang II (and ACE mRNA expression) and NO (and eNOS/iNOS mRNA expression) in vivo and in vitro (Acosta et al. 2009; Girsh et al. 1996a; Hayashi \& Miyamoto 1999; Hinckley \& Milvae 2001; Miyamoto et al. 1997). A recent study indicated that PGF $_{2 \alpha}$ stimulated mRNA expression of EDN1, ACE, eNOS and iNOS in the midcycle CL (Shirasuna et al, 2010b). Contrary to the midcycle CL, PGF ${ }_{2 \alpha}$ significantly decreased EDN1 and eNOS mRNA expression in the early CL (Shirasuna et al. 2010b). Therefore, PGF likely has a dual function depending on the stage of the luteal phase, acting as a luteotrophic factor (in the early CL) and a luteolytic factor (in the midcycle CL) in the cow (Fig. 3).

\section{Conclusions}

Development of the bovine CL occurs rapidly and in a time dependent manner within 1 week after ovulation, with morphologic and biochemical changes in the cells of the theca interna and granulosa cells of the preovulatory follicle. These changes involve luteinisation of steroidogenic cells and angiogenesis to establish luteal function (progesterone secretion). Angiogenic factors such as FGF2 and VEGF have a crucial role in CL development in ruminants. Additionally, the luteolysin $\mathrm{PGF}_{2 a}$ has a stage-specific action depending on the stage of luteal development (early vs. mid) during the oestrous cycle in the cow. Taken together, $\mathrm{PGF}_{20}$ appears to possess a dual function, acting as a luteotrophic or an anti-luteolytic factor by stimulating angiogenic factors in the early CL but acting essentially as a luteolytic factor by stimulating vasoactive-and PG-related factors and by inhibiting angiogenic factors, in the midcycle $\mathrm{CL}$ in the cow.

Clearly, the main function of the $\mathrm{CL}$ is to produce progesterone, which is a prerequisite for survival of the embryo, implantation and maintenance of pregnancy. In the cow, maternal concentrations of progesterone have a marked influence on the development of the embryo and its ability to produce interferon $\tau($ IFN $\tau)$. Mann et al. (1999) indicated that a late rise in progesterone after post-ovulation or inadequate progesterone secretion during the early luteal phase resulted in the development of compromised embryos with limited ability to produce IFN $\tau$ during the maternal recognition period (d 16 after insemination). In contrast, d 16 embryos of cows with an earlier rise in progesterone secretion were more elongated and produced large amounts of IFN $\tau$ (Mann et al. 1999). Moreover, the progesterone concentration in milk of pregnant cows was significantly higher than cows that were mated but not pregnant cows on $\mathrm{d} 6$ after insemination (Mann et al. 1999). These findings strongly suggest that an effective and immediate increase in progesterone is critical in stimulating proper embryo development and IFN $\tau$ synthesis. 
Secretion of adequate amounts of progesterone during luteal development requires proper differentiation and luteinisation of theca and granulosa cells into luteal cells, growth of blood vessels, and the establishment of a blood supply (angiogenesis). Inadequate luteinisation and angiogenesis during the early luteal phase results in poor progesterone secretion causing compromised embryo development and a reduction in fertility. Further investigation into the precise role of luteinisation and angiogenesis during luteal formation and development may provide new insight for better fertility in the cow.

\section{Acknowledgements}

Authors acknowledge Dr. Michael F. Smith, University of Missouri, MO, USA for constructive criticisms to improve the manuscript. This study was supported by a Grant-in-Aid for Scientific Research of the Japan Society for the Promotion of Science (JSPS) and the Global Center of Excellence (GCOE) Program, Ministry of Education, Culture, Sports, Science and Technology, Japan. K. S. was supported by JSPS Research Fellowships for Young Scientists.

\section{References}

Acosta TJ, Bah MB, Korzekwa A, Woclawek-Potocka I, Markiewicz W, Jaroszewski Jj, Okuda K \& Skarzynski D) 2009 Acute changes in circulating concentrations of progesterone and nitric oxide and partial pressure of oxygen during prostaglandin F2alpha-induced luteolysis in cattle. Journal of Reproduction and Development 55, 149-155.

Acosta TJ, Ozawa T, Kobayashi S, Hayashi K, Ohtani M, Kraetzl WD, Sato K, Schams D \& Miyamoto A 2000 Periovulatory changes in the local release of vasoactive peptides, prostaglandin F2alpha, and steroid hormones from bovine mature follicles in vivo. Biology of Reproduction 63, 1253-1261.

Acosta TJ, Yoshizawa N, Ohtani M \& Miyamoto A 2002 Local changes in blood flow within the early and midcycle corpus luteum after prostaglandin F2alpha injection in the cow. Biology of Reproduction 66, 651-658.

Algire JE, Srikandakumar A, Guilbault LA \& Downey BR 1992 Preovulatory changes in follicular prostaglandins and their role in ovulation in cattle. Canadian Journal of Veterinary Research 56, 67-69.

Alila HW \& Hansel W 1984 Origin of different cell types in the bovine corpus luteum as characterized by specific monoclonal antibodies. Biology of Reproduction 31, 1015-1025.

Amselgruber W, Sinowatz F, Schams D \& Skottner A 1994 Immunohistochemical aspects of insulin-like growth factors I and II in the bovine corpus luteum. Journal of Reproduction and Fertility 101, 445-451.

Augustin HG, Braun K, Telemenakis I, Modlich U \& Kuhn W 1995 Ovarian angiogenesis. Phenotypic characterization of endothelial cells in a physiological model of blood vessel growth and regression. American lournal of Pathology 147, 339-351.

Bauer M, Schilling N \& Spanel-Borowski K 2003 Development and regression of non-capillary vessels in the bovine corpus luteum. Cell Tissue Research 311, 199-205.

Beard J 1897 The span of gestation and the cause of birth: a study of the critical period and its effects in mammalia.

Beindorff N, Nagai K, Shirasuna K, Herzog K, Hoeffmann K, Sasaki M, Bollwein H, Miyamoto A 2010 Vascular changes in the corpus luteum during early pregnancy in the cow. Journal of Reproduction and Development 56, 263-270.

Berisha B, Meyer H \& Schams D 2010 Effect of prostaglandin F2alpha on local luteotropic and angiogenic factors during induced functional luteolysis in the bovine corpus luteum. Biology of Reproduction, 82, 940-947.

Berisha B, Schams D, Kosmann M, Amselgruber W \& Einspanier R 2000a Expression and localisation of vascular endothelial growth factor and basic fibroblast growth factor during the final growth of bovine ovarian follicles. Journal of Endocrinology 167, 371-382.

Berisha B, Schams D, Kosmann M, Amselgruber W \& Einspanier R 2000b Expression and tissue concentration of vascular endothelial growth factor, its receptors, and localization in the bovine corpus luteum during estrous cycle and pregnancy, Biology of Reproduction 63, 1106-1114.

Berisha B, Steffl M, Amselgruber W \& Schams D 2006 Changes in fibroblast growth factor 2 and its receptors in bovine follicles before and after GnRH application and after ovulation. Reproduction 131, 319-329.

Berndtson AK, Weaver CJ \& Fortune JE 1996 Differential effects of oxytocin on steroid production by bovine granulosa cells. Molecular and Cellular Endocrinology 116, 191-198.

Choudhary E, Costine BA, Wilson ME, Inskeep EK \& Flores JA 2004 Prostaglandin F2alpha (PGF2alpha) independent and dependent regulation of the 
bovine luteal endothelin system. Domestic Animal Endocrinology 27, 63-79.

Coiter V 1573 Externarum et internarum principalium humani corporis partium tabulae microform: atque exercitationes observationesque, novis, diversis, ac artificosissimus figeris illustratae, philosophis, medicis, in primis autem anatomico studio addictis summe utiles, In Officina Theodorici Gerlatzeni.

Corner GW \& Allen WM 1929 Normal growth and implantation of embryos after very early ablation of the ovaries, under the influence of extracts of the corpus luteum. American lournal of Physiology $\mathbf{8 8}$, 340-346,

Couet J, Martel C, Dupont E, Luu-The V, Sirard MA, Zhao HF, Pelletier G \& Labrie F 1990 Changes in 3 beta-hydroxysteroid dehydrogenase/delta 5-delta 4 isomerase messenger ribonucleic acid, activity and protein levels during the estrous cycle in the bovine ovary. Endocrinology 127, 2141-2148.

Curry TE, Ir. \& Smith MF 2006 Impact of extracellular matrix remodeling on ovulation and the folliculoluteal transition. Seminars in Reproductive Medicine 24, 228-241.

De Graaf R \& Mullierum D 1943 Organis Generationi Inservientibus. Leyden, 1672, translated by G. W. Corner. Essays in Biology, Univ. of California Press.

Einspanier R, Miyamoto A, Schams D, Muller M \& Brem G 1990 Tissue concentration, mRNA expression and stimulation of IGF-I in luteal tissue during the oestrous cycle and pregnancy of cows, Journal of Reproduction and Fertility 90, 439-445.

Farin CE, Moeller CL, Sawyer HR, Gamboni F \& Niswender GD 1986 Morphometric analysis of cell types in the ovine corpus luteum throughout the estrous cycle. Biology of Reproduction 35, 1299-1308.

Findlay JK 1986 Angiogenesis in reproductive tissues. Journal of Endocrinology 111, 357-366.

Fisch B, Margara RA, Winston RM \& Hillier SG 1989 Cellular basis of luteal steroidogenesis in the human ovary. Journal of Endocrinology 122, 303-311.

Frenkel L 1903 Die Funktion des Corpus luteum. Archiv. Gynaekol. (Munich) 68, 438-443.

Fraser HM, Dickson SE, Lunn SF, Wulff C, Morris KD, Carroll VA \& Bicknell R 2000 Suppression of luteal angiogenesis in the primate after neutralization of vascular endothelial growth factor. Endocrinology 141, 995-1000.

Ginther OJ, Araujo RR, Palhao MP, Rodrigues BL \& Beg MA 2009 Necessity of sequential pulses of prostaglandin F2alpha for complete physiologic luteolysis in cattle. Biol Reprod 80, 641-648.

Girsh E, Milvae RA, Wang W \& Meidan R 1996a Effect of endothelin-1 on bovine luteal cell function: role in prostaglandin F2alpha-induced antisteroidogenic action. Endocrinology 137, 1306-1312.

Girsh E, Wang W, Mamluk R, Arditi F, Friedman A, Milvae RA \& Meidan R 1996b Regulation of endothelin-1 expression in the bovine corpus luteum: elevation by prostaglandin F2alpha. Endocrinology $137,5191-5196$.
Gospodarowicz D, Cheng J, Lui GM, Baird A, Esch F \& Bohlen P 1985 Corpus luteum angiogenic factor is related to fibroblast growth factor. Endocrinology 117, 2383-2391.

Grazul-Bilska AT, Redmer DA \& Reynolds LP 1991 Secretion of angiogenic activity and progesterone by ovine luteal cell types in vitro. Journal of Animal Science 69, 2099-2107.

Green MP, Mann GE \& Hunter MG 2007 Luteal characteristics and progesterone production on day 5 of the bovine oestrous cycle. Reproduction in Domestic Animal 42, 643-647.

Hayashi K \& Miyamoto A 1999 Angiotensin II interacts with prostaglandin F2alpha and endothelin-1 as a local luteolytic factor in the bovine corpus luteum in vitro. Biology of Reproduction 60, 1104-1109.

Hazzard TM, Molskness TA, Chaffin CL \& Stouffer RL 1999 Vascular endothelial growth factor (VEGF) and angiopoietin regulation by gonadotrophin and steroids in macaque granulosa cells during the periovulatory interval. Molecular Human Reproduction 5, 1115-1121.

Henricks DM, Long JT, Hill JR \& Dickey JF 1974 The effect of prostaglandin F2alpha during various stages of the oestrous cycle of beef heifers. Journal of Reproduction and Fertility 41, 113-120.

Hinckley ST \& Milvae RA 2001 Endothelin-1 mediates prostaglandin F2alpha-induced luteal regression in the ewe. Biology of Reproduction 64, 1619-1623.

Hojo T, Al-Zi'abi MO, Skarzynski DJ, Acosta TJ \& Okuda $K 2009$ Changes in the vasculature of bovine corpus luteum during the estrous cycle and prostaglandin F2alpha-induced luteolysis. lournal of Reproduction and Development 55, 512-517.

Kano MR, Morishita Y, Iwata C, Iwasaka S, Watabe I, Ouchi Y, Miyazono K, Miyazawa K 2005 VEGF-A and FGF-2 synergistically promote neoangiogenesis through enhancement of endogenous PDGF-BPDGFRbeta signaling. Journal of Cell Science $\mathbf{1 1 8}$, 3759-3768.

Kashiwagi S, Kajimura M, Voshimura V \& Suematsu M 2002 Nonendothelial source of nitric oxide in arterioles but not in venules: alternative source revealed in vivo by diaminofluorescein microfluorography. Circulation Research 91, e55-64.

Kesler DJ, Elmore RG, Brown EM \& Garverick HA 1981 Gonadotropin releasing hormone treatment of dairy cows with ovarian cysts. I. Gross ovarian morphology and endocrinology. Theriogenology 16, 207-217.

Khan-Dawood FS, Gargiulo AR, Dawood MY 1994 In vitro microdialysis of the ovine corpus luteum of pregnancy: effects of insulin-like growth factor on progesterone secretion. Biology of Reproduction 51, 1299-1306.

Kobayashi S, Berisha B, Amselgruber WM, Schams D \& Miyamoto A 2001 Production and localisation of angiotensin II in the bovine early corpus luteum: a possible interaction with luteal angiogenic factors and prostaglandin F2alpha. lournal of Endocrinology 170, 369-380. 
Koch AE, Polverini PJ, Kunkel SL, Harlow LA, DiPietro LA, Elner VM, Elner SG, Strieter RM 1992 Interleukin-8 as a macrophage-derived mediator of angiogenesis. Science 258, 1798-1801.

Levy N, Kobayashi S, Roth Z, Wolfenson D, Miyamoto A \& Meidan R 2000 Administration of prostaglandin F2alpha during the early bovine luteal phase does not alter the expression of ET-1 and of its type A receptor: a possible cause for corpus luteum refractoriness. Biology of Reproduction 63, 377-382.

Li J, Perrella MA, Isai JC, Yet SF, Hsieh CM, Yoshizumi M, Patterson C, Endege WO, Zhou F \& Lee ME 1995 Induction of vascular endothelial growth factor gene expression by interleukin-1 beta in rat aortic smooth muscle cells. Journal of Biological Chemistry 270, 308-312.

Loeb L 1906 The formation of the corpus luteum in the guinea pig. Journal of American Medical Association 46, 416-423.

Maeng YS, Choi HJ, Kwon JY, Park YW, Choi KS, Min JK, Kim YH, Suh PG, Kang KS, Won MH, Kim YM \& Kwon YG 2009 Endothelial progenitor cell homing: prominent role of the IGF2-IGF2R-PLCbeta2 axis. Blood 113, 233-243.

Malpighi M 1897 De Structura Glandarum Cong/obatarum.

Mann GE, Lamming GE, Robinson RS \& Wathes DC 1999 The regulation of interferon-tau production and uterine hormone receptors during early pregnancy. Journal of Reproduction and Fertility Supplement 54, 317-328.

McCracken JA, Custer EE \& Lamsa JC 1999 Luteolysis: a neuroendocrine-mediated event. Physiological Reviews 79, 263-323.

Milvae RA \& Hansel W 1983 Prostacyclin, prostaglandin F2alpha and progesterone production by bovine luteal cells during the estrous cycle. Biology of Reproduction 29, 1063-1068.

Miyamoto A, Kobayashi S, Arata S, Ohtani M, Fukui Y \& Schams D 1997 Prostaglandin F2alpha promotes the inhibitory action of endothelin-1 on the bovine luteal function in vitro. lournal of Endocrinology 152, R7-11.

Miyamoto A, Okuda K, Schweigert FJ \& Schams D 1992 Effects of basic fibroblast growth factor, transforming growth factor-beta and nerve growth factor on the secretory function of the bovine corpus luteum in vitro. Journal of Endocrinology 135, 103-114.

Miyamoto A \& Schams D 1991 Oxytocin stimulates progesterone release from microdialyzed bovine corpus luteum in vitro. Biology of Reproduction 44, 1163-1170.

Miyamoto A, Shirasuna K \& Sasahara K 2009 Local regulation of corpus luteum development and regression in the cow: impact of angiogenic and vasoactive factors. Domestic Animal Endocrinology 37, 159-169.

Miyamoto A, von Lutzow H \& Schams D 1993 Acute actions of prostaglandin F2alpha, E2, and 12 in microdialyzed bovine corpus luteum in vitro, Biology of Reproduction 49,423-430,

Moor RM, Hay MF \& Seamark RF 1975 The sheep ovary: regulation of steroidogenic, haemodynamic and structural changes in the largest follicle and adjacent tissue before ovulation. Iournal of Reproduction and Fertility 45, 595-604.

Murayama C, Miyazaki $H$, Miyamoto A \& Shimizu $T$ 2008 Involvement of Ad4BP/SF-1, DAX-1, and COUPTFII transcription factor on steroid production and luteinization in ovarian theca cells. Molecular and Cellular Biochemistry 314, 51-58.

Murdoch WJ \& Dunn TG 1983 Luteal function after ovulation blockade by intrafollicular injection of indomethacin in the ewe. Journal of Reproduction and Fertility 69, 671-675.

Niswender GD, Juengel JL, Silva PJ, Rollyson MK \& McIntush EW 2000 Mechanisms controlling the function and life span of the corpus luteum. Physiological Reviews 80, 1-29.

Niswender GD, Reimers TJ, Diekman MA \& Nett TM 1976 Blood flow: a mediator of ovarian function. Biology of Reproduction 14, 64-81.

O'Shea ID, Rodgers RJ \& D'Occhio MJ 1989 Cellular composition of the cyclic corpus luteum of the cow. Journal of Reproduction and Fertility 85, 483-487.

Okuda K, Uenoyama Y, Lee KW, Sakumoto R \& Skarzynski D 1998 Progesterone stimulation by prostaglandin F2alpha involves the protein kinase C pathway in cultured bovine luteal cells, lournal of Reproduction and Development 44, 79-84.

Reynolds LP, Grazul-Bilska AT \& Redmer DA 2000 Angiogenesis in the corpus luteum. Endocrine 12, $1-9$.

Robinson RS, Hammond Al, Mann GE \& Hunter MG 2008. A novel physiological culture system that mimics luteal angiogenesis. Reproduction 135, 405-413.

Robinson RS, Woad KJ, Hammond AJ, Laird M, Hunter MG \& Mann GE 2009 Angiogenesis and vascular function in the ovary. Reproduction 138, 869-881.

Sakamoto K, Miwa K, Ezashi T, Okuda-Ashitaka E, Okuda K, Houtani T, Sugimoto T, Ito S \& Hayaishi O 1995 Expression of mRNA encoding the prostaglandin F2alpha receptor in bovine corpora lutea throughout the oestrous cycle and pregnancy. lournal of Reproduction and Fertility 103, 99-105.

Sakumoto R, Berisha B, Kawate N, Schams D \& Okuda K 2000 Tumor necrosis factor-alphá and its receptor in bovine corpus luteum throughout the estrous cycle. Biology of Reproduction 62, 192-199.

Sales KJ, List T, Boddy SC, Williams AR, Anderson RA, Naor Z \& Jabbour HN 2005 A novel angiogenic role for prostaglandin F2alpha-FP receptor interaction in human endometrial adenocarcinomas. Cancer Research 65, 7707-7716,

Sauerwein H, Miyamoto A, Gunther J, Meyer $\mathrm{HH}$ \& Schams D 1992 Binding and action of insulin-like growth factors and insulin in bovine luteal tissue during the oestrous cycle lournal of Reproduction and Fertility 96, 103-115.

Schams D, Amselgruber W, Einspanier R, Sinowatz F \& Gospodarowicz D 1994 Localization and tissue concentration of basic fibroblast growth factor in the bovine corpus luteum. Endocrine 2, 907-912.

Schams D \& Berisha B 2004 Regulation of corpus luteum 
function in cattle: an overview. Reproduction in Domestic Animal 39, 241-251.

Schams D, Berisha B, Kosmann M \& Amselgruber WM 2002 Expression and localization of IGF family members in bovine antral follicles during final growth and in luteal tissue during different stages of estrous cycle and pregnancy. Domestic Animal Endocrinology 22, 51-72.

Schams D, Kosmann M, Berisha B, Amselgruber WM \& Miyamoto A 2001 Stimulatory and synergistic effects of luteinising hormone and insulin like growth factor 1 on the secretion of vascular endothelial growth factor and progesterone of cultured bovine granulosa cells. Experimental and Clinical Endocrinology \& Diabetes 109, 155-162.

Shemesh M \& Hansel W 1975 Stimulation of prostaglandin synthesis in bovine ovarian tissues by arachidonic acid and luteinizing hormone. Biology of Reproduction 13, 448-452.

Shimizu T, Jiang JY, Jijima K, Miyabayashi K, Ogawa Y, Sasada H \& Sato E 2003 Induction of follicular development by direct single injection of vascular endothelial growth factor gene fragments into the ovary of miniature gilts. Biology of Reproduction 69, 1388-1393.

Shimizu T, Sudo N, Yamashita H, Murayama C, Miyazaki H \& Miyamoto A 2009 Histone $\mathrm{H} 3$ acetylation of StAR and decrease in DAX-1 is involved in the luteinization of bovine granulosa cells during in vitro culture. Molecular and Cellular Biochemistry 328, 41-47.

Shirasuna K, Asahi T, Sasaki M, Shimizu T \& Miyamoto A 2010a Distribution of arteriolovenous vessels, capillaries and eNOS expression in the bovine corpus luteum during the estrous cycle: a possible implication of different sensitivity by luteal phase to PGF2alpha in the increase of luteal blood flow. lournal of Reproduction and Development 56, 124-130.

Shirasuna K, Sasahara K, Matsui M, Shimizu T \& Miyamoto A 2010b Prostaglandin F2alpha differentially affects mRNA expression relating to angiogenesis, vasoactivation and prostaglandins in the early and mid corpus luteum in the cow. Joumal of Reproduction and Development 56, 428-436.

Shirasuna K, Watanabe S, Asahi T, Wijagunawardane MPB, Sasahara K, Jiang C, Matsui M, Sasaki M, Shimizu T, Davis IS \& Miyamoto A 2008 Prostaglandin F2alpha increases endothelial nitric oxide synthase in the periphery of the bovine corpus luteum: the possible regulation of blood flow at an early stage of luteolysis. Reproduction 135, 527-539.

Short RE, Staigmiller RB, Bellows RA \& Ford SP 1995 Endocrine responses in cows fed Ponderosa pine needles and the effects of stress, corpus luteum regression, progestin, and ketoprofen. lournal of Animal Science 73, 198-205.

Silva PJ, Juengel JL, Rollyson MK \& Niswender GD 2000 Prostaglandin metabolism in the ovine corpus luteum: catabolism of prostaglandin F2alpha (PGF2alpha) coincides with resistance of the corpus luteum to PGF2alpha. Biology of Reproduction 63, 1229-1236.

Sirois J 1994 Induction of prostaglandin endoperoxide synthase-2 by human chorionic gonadotropin in bovine preovulatory follicles in vivo. Endocrinology $135,841-848$.

Skarzynski DJ, Kobayashi S \& Okuda K 2000 Influence of nitric oxide and noradrenaline on prostaglandin F2alpha-induced oxytocin secretion and intracellular calcium mobilization in cultured bovine luteal cells. Biology of Reproduction 63, 1000-1005.

Slotta K, Ruschig H \& Fels E 1934 Reindarstellung der Hormone aus dem corpus luteum. Berich. Disch. Chem. Gesellschaft 67, 1270.

Smith MF, McIntush EW, Ricke WA, Kojima FN \& Smith GW 1999 Regulation of ovarian extracellular matrix remodelling by metalloproteinases and their tissue inhibitors: effects on follicular development, ovulation and luteal function. Journal of Reproduction and Fertility Supplement 54, 367-381.

Stirling D, Magness RR, Stone R, Waterman MR \& Simpson ER 1990 Angiotensin II inhibits luteinizing hormone-stimulated cholesterol side chain cleavage expression and stimulates basic fibroblast growth factor expression in bovine luteal cells in primary culture. Journal of Biological Chemistry 265, 5-8.

Tsai S\}, Juengel JL \& Wiltbank MC 1997a Hormonal regulation of monocyte chemoattractant protein-1 messenger ribonucleic acid expression in corpora lutea. Endocrinology 138, 4517-4520.

Tsai SJ \& Wiltbank MC 1997b Prostaglandin F2alpha induces expression of prostaglandin $\mathrm{G} / \mathrm{H}$ synthase-2 in the ovine corpus luteum: a potential positive feedback loop during luteolysis. Biology of Reproduction $\mathbf{5 7}$, 1016-1022.

Tsai Sj \& Wiltbank MC 1998 Prostaglandin F2alpha regulates distinct physiological changes in early and mid-cycle bovine corpora lutea. Biology of Reproduction 58, 346-352.

Voss AK \& Fortune JE 1991 Oxytocin secretion by bovine granulosa cells: effects of stage of follicular development, gonadotropins, and coculture with theca interna. Endocrinology 128, 1991-1999.

Voss AK \& Fortune JE 1993 Levels of messenger ribonucleic acid for cytochrome P450 17 alphahydroxylase and $\mathrm{P} 450$ aromatase in preovulatory bovine follicles decrease after the luteinizing hormone surge. Endocrinology 132, 2239-2245.

Wiltbank MC, Dysko RC, Gallagher KP \& Keyes PL 1988 Relationship between blood flow and steroidogenesis in the rabbit corpus luteum. Journal of Reproduction and Fertility 84, 513-520.

Wiltbank MC, Shiao TF, Bergfelt DR \& Ginther OJ 1995 Prostaglandin F2alpha receptors in the early bovine corpus luteum. Biology of Reproduction 52, 74-78.

Wintersteiner O \& Allen WM 1934 Crystalline progestin. lournal of Biological Chemistry 107, 321-336.

Woad KJ, Hammond AJ, Hunter M, Mann GE, Hunter MG \& Robinson RS 2009 FGF2 is crucial for the development of bovine luteal endothelial networks in vitro. Reproduction 138, 581-588.

Wright MF, Sayre B, Keith Inskeep EK \& Flores JA 2001 Prostaglandin F2alpha regulation of the bovine corpus luteum endothelin system during the early 
and midluteal phase. Biology of Reproduction $\mathbf{6 5}$, $1710-1717$

Wulff C, Wilson $\mathrm{H}$, Wiegand S\}, Rudge IS \& Fraser HM 2002 Prevention of thecal angiogenesis, antral follicular growth, and ovulation in the primate by treatment with vascular endothelial growth factor Trap R1R2. Endocrinology 143, 2797-2807.

Yamashita H, Kamada D, Shirasuna K, Matsui M, Shimizu T, Kida K, Berisha B, Schams D \& Miyamoto A 2008 Effect of local neutralization of basic fibroblast growth factor or vascular endothelial growth factor by a specific antibody on the development of the corpus luteum in the cow. Molecular Reproduction and Development 75, 1449-1456.

Yoshida S, Yoshida A \& Ishibashi T 2004 Induction of
IL-8, MCP-1, and bFGF by TNF-alpha in retinal glial cells: implications for retinal neovascularization during post-ischemic inflammation. Graefes Arch Clin Exp Ophthalimol 242, 409-413.

Zheng J, Redmer DA \& Reynolds LP 1993 Vascular development and heparin-binding growth factors in the bovine corpus luteum at several stages of the estrous cycle. Biology of Reproduction 49, 1177-1189. 